other omissions are more than compensated by the soundest modern account available of plate and shell theory, including a new final chapter "which deals with methods of deriving membrane theory, inextensional theory, and bending theory, by asymptotic expansions of the three-dimensional linear elastic equations". This account should prove of considerable importance to ongineers, and will save much analytical effort, once its implications have been digested. To summarize, the second edition of Green and Zerna is not a textbook for boginners, and it is not a definitive treatise, but for the mature student it will provide an almost inexhaustible mine of enduring information.

What Green and Zerna do for theoretical elasticity, Cristescu does for dynamic plasticity. He is a well equipped mathematician who has imposed order on a vast mass of material by combining clarity of mind with wealth of learning. The dynamic plastic continuum presents considerably more complications than the simple linear or even non-linear elastic continuum. Physical ideas and arguments inevitably play a much greater part. The experimental material is diversified and not always well defined. Above all, numerical mathematics must be brought in at the outset, not merely as a tool but as an equal partner with mathematical analysis and with experiment. As the author remarks, "the creation of high speed computers with huge memories can be considered a revolution for the development of the theoretical problems of dynamic plasticity". For example, the loading/unloading boundary, even for one-dimensional problems, has so far remained inaccessible to mathematical treatment, but can be located for any initial and boundary conditions using a computer. Similar remarks hold for the reflexion of waves from the fixed or moving ends of an extensible string. Bearing in mind all the inherent difficulties of the subject, not excluding that of a Rumanian writing almost impeccable English for a Dutch publisher, Cristescu has produced an astonishing book that can be read with equal profit by the beginner and the advanced research worker. More than 700 references are cited, drawn from East and West, ranging in time from Coulomb's celebrated 1773 memoir to numerous papers of 1966 vintage, including a few on dislocation mechanisms, but curiously omitting Hill's "Plasticity". A succossful balance is preserved as between mathematical, physical and experimental aspects, though some experimental work might have been more critically treated.

M. A. JASwON

\section{OPERATION ORSANCO}

\section{The Orsanco Story}

Water Quality Management in the Ohio Valley under an Interstate Compact. By Edward J. Cleary. Pp. xvi+ 335. (Baltimore, Maryland : The Johns Hopkins Press; London: Oxford University Press, 1967. Published for Resources for the Future, Inc.). $81 s$. net boards; $28 s .6 d$. paperback.

RIVER pollution is ono major feature of our high standards of living, and the Ohio River, which flows down one of the most populated and industrialized valleys in the United States, had almost reached the condition of an open sewer in 1935. The problems of combating this scale of pollution seemed insoluble, where the catchmont area totals 155,000 square miles and embraces the territories of eight states, where well over eleven million people contribute to sewage entering the river, where industrial effluents vary from paper waste to brine and phenolic compounds, and where the majority of the public were apathetic and unaware of the real situation.

On the other hand, the threat of disease through water supply contamination had been emphasized in 1930 by widespread gastro-enteritis, the cost of adequato treatment of water extracted from the river for public use was increasing, and the recreational facilities, principally boating and fishing, were fast deteriorrting.

The story of ORSANCO (Ohio River Valley Water Sanitation Commission) is an account of how these problems wore approached and controlled by an interstate compact the formulation and setting up of which is no mean achievement in a country where the individual states are proud of their independence and jealous of any form of federal control. Yet such was the will and vision of a handful of people that not only was such a compact negotiated, it was also made to work and work well. Public opinion was aroused, industrial enterprises offered help, municipalities built new sewage works, large-scale surveys were undertaken, and all for a cost of less than a ponny per year per head. Federal aid has become inereasingly important in recent years, but initially the cost of the programme was to a very large extent met by contributions from the member states.

Quite apart from the problems of scientific assessment of the river conditions and of ways and means of combating the various forms of pollution, the welding of such a legally viable compact, which could be enforced in case of need, remains an achieverment the magnitude of which can only be appreciated by reading the book itself. In many ways, The Orsanco Story is a legal history of interstate relations and bargaining, and Edward J. Cleary, the executivo director of ORSANCO, makes it both readable and exciting.

The story does not stop with the end of the book, however, which takes us up to December 1966. New problems are continually arising, the value of the dollar falls each year, federal control is increasing, and the role of ORSANCO is changing to meet the new demands imposed on it. Nevertheless, this book records the history of what the American Society of Civil Engineers, on selecting ORSANCO for its "outstanding achievoment award" in 1963, called "the most effective large-scale water pollution abatement programme ever undertaken in the Western Hemisphere"; and it affords a measure of comfort for those who stand appalled at the menace of the increasing garbage of civilization. R. S. WILSON

\section{AIR PHOTOS}

\section{Aerial Discovery Manual}

By Carl H. Strandberg. (Wiley Series on Photographie Science and Technology and the Graphic Arts.) Pp. 249. (New York and London: John Wiley and Sons, Inc., 1967.) $140 s$.

'Turs book, which is planned as an American college (or home study) training courso in air photo interpretation, is divided into three sections-"Aerial Photographic Interpretation", "Photo "'eology" and "Photo Hydrology".

'The first section deals with the general principles and techniques of air photo interpretation and discusses the equipment and methods used in air photo studies. In spite of their importance little is said about stereoscopes other than the simple lens type. A comparative assessment of the three most commonly used stereoseopes would have been useful. The author reveals a lack of photogrammetric knowledge when he writes of "two methods used to determine the exact scale of aerial photograph", and nowhere is there reference to the special geometric characteristics of a vertical aerial photograph. The methods suggested for determining distances and heights are somewhat crude, and it is not mado at all clear why a vertical aerial photograph cannot be treated as a true to scale plan.

Much of the second section, which deals with photo geology, is taken up with a basic introduction to geology, 